\title{
O PAPIESKIEJ TWÓRCZOŚCI TADEUSZA NOWAKOWSKIEGO
}

\author{
Krzysztof DOROSZ SJ (Toruń)
}

„Mówi reporter papieski naszej rozgłośni...” — w taki sposób spikerzy Radia Wolna Europa zapowiadali antenowe wypowiedzi Tadeusza Nowakowskiego, który po pamiętnym wyborze kard. Karola Wojtyły na Stolicę Piotrową został skierowany do medialnej obsługi pontyfikatu Papieża-Polaka. To nowe zadanie doświadczony dziennikarz i poczytny literat uznawał za największą i najpiękniejszą przygodę swego życia. „Wielka duma przepełnia nasze serca” — mówił podniosłym i nieco onieśmielonym głosem jako sprawozdawca Mszy inauguracyjnej „Papieża z dalekiego kraju”. Jak opowiadać o dziejących się w Rzymie i w Watykanie historycznych wydarzeniach, które całkowicie zaskoczyły świat i Polaków?

\section{Reporter Papieża}

Nowy sposób sprawowania posługi Piotrowej spowodował niebywały wzrost zainteresowania światowych mediów tematyką papieską, do której oddelegowano najlepszych dziennikarzy. A takim talentem w RWE był niewątpliwie Tadeusz Nowakowski, poczytny pisarz, niezwykły erudyta, obdarzony świetną pamięcią, łączący niepospolitą inteligencję z poczuciem humoru. Podobno na wieść o wyborze kard. Wojtyły na Papieża, ówczesny dyrektor Rozgłośni Polskiej, Zygmunt Michałowski, przestraszony trudnością czekających zadań, miał jęknąć: „O Boże! Jeszcze nam tego brakowało!”2 . Nie dziwi zatem fakt, że właśnie Nowakowskiemu powierzono niezwykle ważną dla redakcji funkcję ,papieskiego reportera”. Choć relacjonował on różne zdarzenia pontyfikatu Jana Pawła II, uwaga rozgłośni skupiła się na papieskich pielgrzymkach. Nowakowski jako reporter uczestniczył w pierwszych trzydziestu ze stu czterech zagranicznych podróży apostolskich, jakie odbył Papież-Polak podczas swojej posługi na Stolicy Piotrowej, poczynając od wyprawy do Meksyku w 1979 roku. Ostatnią, opisaną podró-

\footnotetext{
${ }^{1}$ „Reportaż z Watykanu” z 22.10.1978: http://www.polskieradio.pl/68/2461/Audio/294742 [dostęp: 13.06.2017].

${ }^{2}$ Wspomnienie Andrzeja Borzyma podczas konferencji: „Radio Wolna Europa - jako mecenas kultury, nauki i sztuki polskiej”, Toruń — Centrum Sztuki Współczesnej, 15-16 XII 2014.
} 
żą z Papieżem, była pielgrzymka do Bangladeszu, Singapuru, na Fidżi, do Nowej Zelandii, Australii i na Seszele, jaka odbyła się pod koniec 1986 roku.

Swoje opowieści i refleksje reporter papieża przedstawiał w różnej postaci: jako krótsze i dłuższe korespondencje, relacje dźwiękowe, sprawozdania, komentarze, które pojawiały się w takich audycjach informacyjnych i publicystycznych, jak „Panorama dnia”, „Fakty, wydarzenia, opinie”, „Przy otwartym mikrofonie”. Dłuższe pogadanki, z których słuchacze mogli dowiedzieć się więcej o szczegółach czy o okolicznościach wydarzeń, zamieszczane były w „Refleksjach przed północą”, w audycji „Przy kawiarnianym stoliku”, czy też w programach na szczególne okazje, tzw. „Special program”. $\mathrm{Na}$ antenie RWE pojawiały się także odczytywane przez samego autora fragmenty już wydanych reportaży papieskich (istnieje 6 takich zbiorów), bądź też tekstów przygotowywanych do publikacji. Słuchacze mogli usłyszeć również relacje dźwiękowe z wieczorów autorskich Nowakowskiego, barwnie opowiadającego o swoich podróżach z Janem Pawłem II. Do tego należy dołączyć emitowane rozmowy z papieskim reporterem, które przeprowadzali z nim: Wiesław Wróblewski, Tadeusz Mieleszko (właśc. Jerzy Kaniewicz), Piotr Załuski, Jan Tyszkiewicz, Konrad Tatarowski.

W tych wywiadach zwykle podsumowywano jedne podróże papieskie i mówiono o przygotowaniach do kolejnych, opisywano kulisy reporterskiej pracy oraz prezentowano kolejne zbiory. Nowakowski nazywał swoją dziennikarsko-pisarską aktywność wielką przygodą umysłu i serca, deklarował przy tym staranie o rzetelność przekazu, a także osobistą atencję i pietyzm dla Papieża, odczuwany przez miliony Polaków. W rozmowie z Tyszkiewiczem podkreślał: „Mam wrodzony szacunek do Papieża, jeśli kogoś obdarza zaufaniem, to nie należy tego zaufania nadużywać"3. W tym wywiadzie, będącym podsumowaniem pielgrzymki do Afryki, zauważył jednak, że warsztat pracy reportera obfituje w niespodzianki, sytuacje nieprzewidywalne, że to jedna wielka ruletka. Tym niemniej — jak zauważył — „największym wrogiem reportera jest rutyna" i ,trzeba zawsze dbać o to, aby reportaż był w substancji ten sam, ale w formie nieco inny", W ten sposób Nowakowski-pisarz odpowiadał na wysuwane wtedy zarzuty, że zanadto dominuje nad bohaterem narracji, bo za dużo tutaj autorskiego ego, a za mało Papieża. Wszak nie ma w tym nic dziwnego - stwierdził w recenzji londyński publicysta, o. Jerzy Mirewicz - bo każdy taki opis jest nacechowany osobistą optyką autora. Ile portretów Jana Pawła II (czy kogokolwiek innego), tyle autoportretów piszących o nim: „Każdy autor daje nam siebie i 'swego' Papieża”. Dlatego słuszne wydało się Mirewiczowi odwrócenie tytułu „Reporter papieża” na „Papież reportera” dla podkreślenia czynnika kreacyjności. Autor opowieści odniósł się do tych uwag, przywołując na swoje „usprawiedliwienie” żartobliwe stwierdzenie samego Jana Pawła II, który z właściwym sobie humorem miał powiedzieć o swoich biografach: „Cieszę się, że o mnie piszą, ale nie pisują na kolanach, bo to niewygodna pozycja"”.

$\mathrm{W}$ tej interesującej rozmowie z Piotrem Załuskim zapytany, jak powstają literackie reportaże o Papieżu, Nowakowski opowiada o etapach ich tworzenia (proces podobny do pracy innych reporterów): najpierw bezpośredni zapis dźwiękowy i codzienny przekaz zebranego materiału w postaci relacji radiowych, potem wzbogacenie zapisu poprzez

\footnotetext{
${ }^{3}$ Audycja „O nas samych” z 31.08.1985: http://www.polskieradio.pl/68/2461/Audio/298872 [dostęp: 13.06.2017].

${ }^{4}$ Tamże.

5 J. Mirewicz, Papież reportera, Przegląd Powszechny — Sodalis Marianus 1981 nr 2 (402), s. 15.

${ }^{6}$ Rozmowa P. Załuskiego z T. Nowakowskim z 30.03.1986: http://www.polskieradio.pl/68/2461/Audio/307788 [dostęp: 13.06.2017].
} 
lekturę lokalnych gazet i wydawnictw, związanych z przyjazdem papieża, pogłębienie tego wszystkiego po samej podróży, pokazanie jej sensu i spodziewanych owoców ${ }^{7}$. „Gdybym pozwolił sobie na nadmiar zmyślenia a niedosyt prawdy — nie brałbym udziału w tych podróżach", usprawiedliwia się Nowakowski, który jako zasadę swego działania deklaruje odpowiedzialność za przekazywane słowo ${ }^{8}$. „Ja tylko zbieram kamyki do mozaiki - do wielkiej monografii, którą pewnie przyszły biograf Jana Pawła II napisze" — podkreśla papieski reporter — ,zastępuję słuchaczowi oko i ucho"9.

Te impresje pozwalają mu tworzyć literackie portrety Jana Pawła II. Pierwsze owoce tej pracy prezentuje pisarz w maju 1979 roku. W audycji specjalnej, emitowanej w związku ze świętem 3 maja, czyta fragmenty opowiadania Solo per i Polacchi, które znalazło się w wydanym rok później zbiorze Reporter Papieża ${ }^{10}$. Narrator opowiada, jak to Papież, spacerując po Ogrodach Watykańskich, snuje wspomnienia z dzieciństwa, rozpamiętując czasy, gdy będąc chłopcem, uczestniczył na krakowskich Błoniach w podniosłych uroczystościach patriotycznych z udziałem marszałka Józefa Piłsudskiego. Nowakowski zestawia w ten sposób dwie wielkie postaci historii Polski i pokazuje, jak patriotyczno-religijny klimat Krakowa kształtował osobowość przyszłego Papieża.

Fragment ten dobrze ilustruje element kreacyjności, zawarty w reporterskich opowieściach. Wszak Nowakowski był dziennikarzem obdarzonym mocną wyobraźnią twórczą, świetną pamięcią, umiejętnościami znakomitego gawędziarza, krasomówcy ${ }^{11}$. Nie zawsze jednak ściśle trzymał się faktów, także wtedy, gdy był sprawozdawcą papieskim. „Reporter papieża” - to typowy impresjonista, zbieracz wrażeń, które następnie przetwarzał na opowieści. Należy je traktować jako wywołane różnymi sytuacjami impresje autora na tematy papieskie, a nie tylko jako zapisy faktograficzne. Dlatego w sferze zgodności z wydarzeniami trzeba je konfrontować z innymi źródła$\mathrm{mi}^{12}$. Tak więc u Nowakowskiego mamy do czynienia ze swoistą grą pomiędzy faktografią a imaginacją, opisami autentycznych zdarzeń a dygresjami — produktami literackiej wyobraźni autora.

Oto kilka przykładów. Lot papieskim samolotem do Irlandii urasta do symbolicznej podróży w czasie i w przestrzeni:

Ino patrzeć jak się flagowy Boeing 747 „Święty Patryk” w Orła Białego przemieni. O błogosławiona demagogio patriotyzmu, pocieszycielko narodów uciśnionych. Ty jesteś jak zdrowie. Jeszcze moment, a uwierzę, że to nie arka dziennikarzy, lecz fruwająca ponad historią łódź napełniona duchami, ta z poezji Słowackiego ${ }^{13}$.

\footnotetext{
${ }^{7}$ Tamże.

${ }^{8}$ Tamże.

${ }^{9}$ Tamże.

${ }^{10}$ Audycja „Pamiątka wiecznie żywa” z 6.05.1979:
}

http://www.polskieradio.pl/68/2461/Audio/299192 [dostęp: 13.06.2017].

${ }^{11}$ Opinie dziennikarzy RWE: A. Krzeczunowicza i A. Świeykowskiego podczas konferencji: „Radio Wolna Europa — jako mecenas kultury, nauki i sztuki polskiej”.

${ }_{12}$ Tamże.

${ }^{13}$ T. Nowakowski, Reporter papieża, wyd. 2 poszerzone, Londyn 1980, s. 94 (dalej: Rep i numer strony). Inne cytowane książki tego autora: W bagażniku Jego Świątobliwości, Londyn 1981 (dalej: Bag); Volo Papale, Londyn 1982 (dalej: V); Boeing świętego Piotra, Londyn 1986 (dalej: B). Wymienione publikacje — a także zbiory: Na skrzydłach nadziei, Londyn 1984 oraz Kwiaty dla Pielgrzyma, Londyn 1987 — wydała Polska Fundacja Kulturalna. 
Różne miejsca pobytu wywołują nieodparte skojarzenia z polską kulturą i przeszłością. Dla takiego twórcy jak Nowakowski - to wygrany los na loterii, o czym pisze przy okazji pobytu w hiszpańskiej Saragossie, a potem na Dominikanie:

W czepku-ś urodzony: wczoraj oglądałeś rzekę, w której Cedro prał ułański proporczyk z krwi aragońskiej, dzisiaj zaś ślizgasz się okiem po kaktusach, pod którymi leżą prochy żołnierzy generała Władysława Jabłonowskiego. Spotkał cię przywilej: dzięki papieskim wojażom pielgrzymujesz po narodowej historii i literaturze (B 146).

Pośród licznych relacji, dygresji, dowcipów i anegdot, z których reporter zręcznie splata swoje opowieści, pojawia się jakby „drugi głos”, spinający reporterskiego Pegaza, przypominając o narracyjnym porządku. Tak jest w relacji z podróży do Stanów Zjednoczonych:

Do Nowego Jorku i Waszyngtonu jeszcze wrócimy, a teraz czym prędzej na gościniec opowieści, bo się jeszcze zgubimy w gąszczu impresji i refleksji. Nie po to klasycy narracji wymyślili sekwencję wydarzeń, tę nitkę Ariadny w labiryncie faktów, by ją ignorować w diariuszu podróży. Chociaż Faulkner uważał, że chronologia ważna jest w protokole policyjnym, nigdy zaś w zapisie literackim (Rep 115).

Takich fragmentów, świadczących o swoistej grze między powinnością sprawozdawcy a wyobraźnią literata, jest więcej, jak choćby w reportażu z pielgrzymki do Afryki:

Reporterze, weź się w garść! Chronologia, sekwencja wydarzeń, jedność czasu i miejsca, wiem, wiem, to bardzo ważne. Lecz czasem trzeba skokami konika miotać się na szachownicy, nizać paciorki obserwacji na rozchybotanej nitce w pośpiechu, zanim się rozlecą na gorącym, afrykańskim wietrze (Rep 173-174).

Te reportaże płynnie przechodzą w opowieści podróżnicze, zauważa sam Nowakowski przy okazji pobytu na Czarnym Lądzie: „Mogę więc znowu rozsypać garść kartek z diariusza podróży, kreując się przy tym prawem kaduka na niegodnego naśladowcę praszczura pątników, Radziwiłła-Sierotki” (Rep 182). W narracjach ujawnia się charakterystyczna cecha reportera, by uchwycić życie na gorąco: „Impresje zbieram za dnia do czapki jak monety. Wieczorem rzucam je na stół. Tu orzeł, tam reszka” (Rep 212). Przedstawia się jako „sygnalista refleksu” i „utrwalacz przelotności”, choć też ulega „pokusie refleksji” (V 65). I bywa także poetą, którego nastrajały niesamowite widoki z okna papieskiego samolotu, jak podczas lotu na Daleki Wschód: ,pod skrzydłami błyszczy archipelag siedmiu tysięcy stu wysp, barwiczką wschodzącego słońca uszminkowany" (Bag 19).

\section{Papież reportera}

Jak został przedstawiony główny bohater opowieści? Nowakowski wielokrotnie podkreśla, że w podziwie dla Jana Pawła II decydującą rolę odgrywa polskość Papieża:

Fascynuje mnie charyzmat rodaka w tiarze i sekret jego niezwykłości. Wielki człowiek objawia się, gdy wielki charakter napotyka na wielkie zadanie. Przyciąga mnie do tej postaci nadzieja, że mocą swej osobowości i blaskiem autorytetu wspomoże nasze dążenie do wolności i niepodległego bytu (Rep 72).

Ta opinia, wyrażona z okazji pierwszej, historycznej wizyty Papieża w ojczyźnie, była nie tylko osobistą wypowiedzią pisarza, ale głosem zbiorowym, wypływającym z przekonania wielu Polaków w kraju i na obczyźnie, niezależnie od religijnego wyznania czy zaangażowania: Jan Paweł II stał się nadzieją dla wolnej Polski. Nowakowskiemu imponuje to, że Pontifex Maximus pozostał żarliwym patriotą, wciąż nawiązuje do 
naszych spraw, a jego wystąpienia są nacechowane polską i chrześcijańską godnością. Ile to charyzmatów mieści w sobie ten wielki syn małych Wadowic! - mówi z podziwem w relacji podsumowującej wizytę Jana Pawła II w Stanach Zjednoczonych ${ }^{14}$. Imponuje fakt, że Papież czyni polskość swoim atutem, a jego uniwersalizm jest zakorzeniony w rodzinnym gnieździe ${ }^{15}$.

Nowakowski wielokrotnie i w różny sposób powtarza, że Jan Paweł II stał się znakomitym ambasadorem sprawy polskiej i naszej kultury. Poprzez osobę Karola Wojtyły i jego wybór, świat zwrócił uwagę na Polskę. Z satysfakcją zauważa, że przyszli badacze tego pontyfikatu będą musieli sięgnąć do polskich źródeł, bo Papież cytuje klasyków naszej literatury. Przez Jana Pawła II ludzie z odległych kontynentów poznają Polskę, a dzieci z dalekich krajów dowiadują się o ojczyźnie Następcy św. Piotra na lekcjach religii. Wszędzie, gdzie Nowakowski dociera z Papieżem, a są to nierzadko egzotyczne zakątki świata, od razu wychwytuje obecnych tam rodaków. Te opowieści — to także elementy barwnej mozaiki polskiej diaspory rozrzuconej po całym świecie. „Mnie zawsze interesują ślady polskie” — podkreśla reporter w rozmowie z Janem Tyszkiewiczem, przed papieską pielgrzymką do Indii ${ }^{16}$.

$Z$ radością odnotowuje Nowakowski wszelkie sygnały, świadczące o tym, że Jan Paweł II stał się autorytetem światowym, także dla ludzi o różnych światopoglądach. Po zamachu, ciesząc się, że bohater powraca do dawnej formy, cytuje głos niewierzącego ,przyjaciela z Harvardu”, który stwierdził, że ,świat stałby się nagle biedniejszy i zimniejszy, gdyby zabrakło tego Papieża” (Bag 111). I dodaje własną opinię: „Cyrenejczyk z Wadowic pomaga nam wszystkim - wierzącym i niewierzącym w niesieniu krzyża. Potrzebuje Go nasza ojczyzna. Potrzebuje Go świat cały" (Bag 119). Podczas pielgrzymki do Japonii stwierdza, że Jan Paweł II stał się dla świata zwiastunem nadziei:

Dokądkolwiek papież przybywa w apostolskiej misji nawet do kraju, w którym chrześcijanie stanowią zaledwie jeden procent ludności, sypią się kartki z księgi zażaleń. Przed kim mają się upośledzeni poskarżyć na swoją krzywdę, jeśli nie przed Zwiastunem Nadziei? Dobrze, że jest taki autorytet na świecie. Człowiek tęskni do Instancji Odwoławczej. Do światła w labiryncie istnienia. Do współczucia i miłosierdzia (Bag 48).

Tam właśnie ofiary z Hiroszimy i Nagasaki zostają skojarzone z zagładą w Auschwitz. Wcześniej, opowiadając o głodujących i umierających z głodu Afrykańczykach, reporter pisał: „powiało Oświęcimiem” (Rep 174). Wyrastający z polskich doświadczeń symbol zagłady stał się dla Nowakowskiego kategorią o powszechnym zasięgu, w myśl powiedzenia, że „świat jest jeden, męka ludzka - uniwersalna” (Bag 69).

Autor reportaży przytacza wiele różnych opinii na temat polskiego Papieża, wśród których pojawiają się nierzadko głosy krytyczne. Większość zdań jest jednak pozytywna, a szczególną uwagę zwracają te, które nie pochodzą od katolików, jak wyznanie amerykańskiego dziennikarza, „do złudzenia podobnego do Tuwima”:

Ja nie jestem teolog, ja nawet nie jestem wierzący, ale ja czuję, ja wiem na pewno, że

14 „Panorama dnia” — 08.10.1979: http://www.polskieradio.pl/68/2461/Audio/306430

[dostęp: 13.06.2017].

${ }^{15}$ „Po Koperniku, Sobieskim i Kościuszce, to chyba czwarty wielki Polak skali światowej. Stale podkreśla swój związek z ojczyzną. Cytuje naszych klasyków, mówi o polskiej historii, kulturze, sztuce. Takiego ambasadora jeszcze nie mieliśmy. Wie, że uniwersalizm zaczyna się w rodzinnym gnieździe" (Rep 89).

${ }^{16}$ Audycja „O nas samych” z 01.02.1986:

http://www.polskieradio.pl/68/2461/Audio/299869 [dostęp: 13.06.2017]. 
ten papież jest czymś więcej niż papieżem, on jest tym przyjacielem, do którego każdy z nas tęskni przez całe życie. My się osobiście nie znamy, ale ja zrobię dla Niego wszystko czego On tylko ode mnie zażąda (Rep 94).

Myli się ten, kto sądzi, że papież wiedzie życie beztroskie — zauważa Nowakowski on też ma swoje kłopoty: „Odpowiedzialność, odwrotna strona wolności. Każdy przełożony dźwiga na sobie to brzemię” (Rep 149). Papieski pontyfikat — to „pielgrzymka bosego pątnika poprzez ściernisko rzeczywistości - pod pięknym niebem pryncypiów”, miał wyznać polski Następca św. Piotra (Rep 245). Przy okazji pielgrzymki do Hiszpanii reporter dodaje: „Miliony ludzi na świecie wierzy, że ten papież nie załamie się pod ciężarem tragicznej powinności” (V 240).

Wśród wykreowanych przez Nowakowskiego papieskich obrazów wyróżnia się scena, którą można uznać za symboliczną. Wydaje się najlepszą, literacką prezentacją Jana Pawła II:

Nie mógł zasnąć. Podszedł do otwartego okna. W świetle księżyca, który nad Rzymem świeci inaczej niż nad Krakowem — jakby reflektor padał na scenę — dojrzał obelisk po środku placu. W cyrku cezarów ochrzczony został krwią pierwszych chrześcijan.

Któż nie stał przed tym pomnikiem, o którym legendy mówią, że wyciosała go niewolnicza ręka w kopalniach Salomona, że spadł z nieba jak meteoryt. I Tasso i Michał Anioł i nasz Norwid. I Mickiewicz z chorągwią swego Legionu, legioniści Dąbrowskiego i Andersa, tułacze na Polskę nieuleczalnie chorzy, emisariusze wolności. To miasto pełne jest pomników na których wyryto imiona i insygnia papieskie. Horacjańskie „Non omnis moriar”, chęć zapisania się w pamięci potomnych, protest przeciw własnej śmiertelności... Co pozostawić po sobie? (Rep 258-259).

Nowakowski wspomina, jak podczas wizyty w ówczesnej RFN (listopad 1980) wręczył bohaterowi opowieści pierwszą edycję Reportera papieża, książkę świeżo wydaną przez „Polską Fundację Kulturalną”. Zareagował życzliwie: „Cieszę się — mówi z uśmiechem — że pisze pan sercem. Znam niektóre rozdziały. Pozostał mi w pamięci opis podróży do Meksyku. Bóg zapłać za ten upominek" (Rep 270).

W obfitej dziś twórczości na temat Jana Pawła II papieskie reportaże Tadeusza Nowakowskiego (które są wciąż mało znane!) wyróżniają się głównie swoimi walorami literackimi. Autorowi zawdzięczamy barwne i dynamiczne opisy podróży PapieżaPolaka oraz żywe portrety ich głównego bohatera. W tej nacechowanej wrażliwością autora prozie czasem przeważa obiektywny opis zdarzeń, innym razem górę bierze kreacyjność, mimo że, co Nowakowski podkreślał w wywiadach, musiał trzymać się faktografii i nie mógł pozwolić sobie na zbytnią lekkość w traktowaniu tematu. Tym niemniej dostrzec można swoistą grę pomiędzy sprawozdawczą narracją a imaginacją, relacją o zdarzeniach a związaną z nimi wyobraźnią. Nowakowski umiejętnie łączy te role, $\mathrm{w}$ ten sposób jego reportaże płynnie przechodzą $\mathrm{w}$ opowieści podróżnicze $\mathrm{i}$ odwrotnie. Przedstawiony w literacki sposób „Papież reportera” nie odbiega wiele od swego pierwowzoru, choć pisarz niewątpliwie potęgował tę niezwykła i urzekającą osobowość, fascynującą nie tylko rodaków, ale i miliony ludzi na całym świecie. Z pewnością „Reporter papieża” starał się jak najlepiej wypełnić powierzone przez kierownictwo RWE niezwykle ważne zadanie. Nic dziwnego, że wykorzystał szerokie możliwości swego warsztatu twórczego, o których była mowa. Zachowywał przy tym podziw i szacunek dla bohatera, który, znany z poczucia humoru i dystansu wobec siebie, darzył autora sympatią i wdzięcznością, nawet jeśli jego opowieści traktował „,z lekkim przymrużeniem oka”. Przecież sam też uprawiał literaturę. 


\section{LITERATURA}

T. Nowakowski, Reporter papieża, wyd. 2 poszerzone, Londyn 1980;

—, W bagażniku Jego Świątobliwości, Londyn 1981;

-, Volo Papale, Londyn 1982;

—, Na skrzydtach nadziei, Londyn 1984;

—, Boeing świętego Piotra, Londyn 1986;

-, Kwiaty dla Pielgrzyma, Londyn 1987;

K. Dorosz SJ, „Sa znaki na ziemi...”. Tadeusza Nowakowskiego reportaże papieskie, [w:] K. Dorosz SJ, Metafizyka wyzwolenia i inne eseje, Kraków 2013, s. 201-219.

S. Melkowski, Reporter Papieża. O prozie dokumentarnej Tadeusza Nowakowskiego, [w:] Emigracyjna literatura czeska i polska: materiały z międzynarodowej konferencji naukowej, pod red. L. Martinek, M. Tichý, Opava 2002;

J. Mirewicz, Papież reportera, „Przegląd Powszechny — Sodalis Marianus 1981 nr 2 (402), s. $15-17$.

\section{POPE JOHN PAUL II IN THE WORKS OF TADEUSZ NOWAKOWSKI}

The article discusses the literary and radio works by Tadeusz Nowakowski, which were inspired by the pontificate of John Paul II. Nowakowski, also known under the pseudonym Tadeusz Olsztyński, a reporter of the Polish Section of Radio Free Europe since 1952, was sent by the radio station to the Holy See after Cardinal Wojtyła was elected Pope in 1978, to comment on this unique pontificate. As a result, he participated in nearly 30 pastoral visits of John Paul II and shared his impressions with the listeners of Radio Free Europe in numerous reports, commentaries and accounts, which later served as a basis for the writing of literary reportages (six such collections were published by the Polish Cultural Foundation in London). On the basis of radio programmes available at the Radio Free Europe audio archives, as well as published reportages, the author of the article analyses the "papal" works by Nowakowski, concentrating on their literary value. It turns out that the "Pope's reporter" managed to skilfully combine journalistic fact-oriented writing with literary creativity in his vivid, impressionistic images of John Paul II's pontificate, displaying at the same time restraint and respect for the hero of his stories. Thanks to Radio Free Europe's assignment and his literary skills he enriched Polish literature with great, although little known, portraits of the Holy Father.

KEY WORDS: Tadeusz Nowakowski; pseudonym Tadeusz Olsztyński; John Paul II — Karol Wojtyła; the Vatican; pastoral visits; Radio Free Europe; literature; reportage; emigration; Polish diaspora. 